Office of Science and Technology says that, despite the demands from pressure groups, the public-consultation exercise did not find a widespread demand for more public involvement in the approval of individual GM products.

There is a fierce debate in Britain over whether GM crops should be grown commercially before the end of a four-year period of research into their environmental effects. Supporters of such a moratorium include the British Medical Association, the government's wildlife advisers English Nature, opposition political parties, environmental and consumer groups, and most of the media.

Research published last week, suggesting that monarch butterflies could be at risk from eating pollen from corn that has been genetically modified to increase resistance to pests (see Nature 399, 214; 1999), intensified calls for a moratorium, and exposed the tensions within government over the issue.

Many in government, including Michael Meacher, the environment minister, and Sir Robert May, the chief scientific adviser, while keen to point out the potential advantages of GM crops, are concerned that they could accelerate the erosion of biodiversity. They are reluctant to approve their commercial introduction until such concerns are allayed.

But others, notably Jack Cunningham, who chairs the ministerial committee on biotechnology, and Lord David Sainsbury, the science minister, are believed to be keen to promote the technology because of its role in the government's efforts at knowledge-based economic development.

EhsanMasood

\title{
Britain backs biotech, seeks tougher regulation
}

[LONDON] Most of the British public is aware of

developments in the

biological sciences, but a

significant proportion

believes that research in

some areas of biotechnology

- notably cloning - is moving

too fast, and that there is too

little regulation.

These are among the findings to emerge from a public consultation on the biosciences commissioned by the government and published last week. They contributed to the government's decision to increase public involvement in overseeing developments in biotechnology (see page 287).

The survey - the largest of its kind to be undertaken in Britain - established the extent of public opposition to biotechnology, which has severely affected the government and industry's timetable for the introduction of genetically modified crops.

Researchers from the polling company Market and Opinion Research

International (MORI) interviewed 1,100 people faceto-face, and conducted six two-day 'focus group' workshops with 123 people. Respondents were asked five categories of questions, including the level of their awareness of the

biosciences and their regulatory arrangements, and the issues they believe should be taken into account in any oversight process.

The public is aware of xenotransplantation and such issues, and is broadly supportive of the benefits of biotechnology, particularly in healthcare. But there is a feeling that information is being held back, particularly regarding answers to questions such as 'why is this development taking place?'. It is also less supportive of cloning and genetic modification in agriculture, and wants its views to be considered when decisions are made.

Many participants could not see the purpose of cloning, and remained concerned about the possibility of human cloning even when told it is illegal.

They also felt they had been kept in the dark about it.

Similarly, respondents did not regard genetically modified food as being of benefit to society, and were unsure as to why it was being produced. The idea of using animal or human genes in plants for consumption was generally not considered acceptable. The most common reason given for GM food was 'to produce more food/have high yields/boost agriculture'. But this was followed closely by 'companies want to make money/have profit'.

When asked about bioscience regulation, 38 per cent believe that there is too little regulation of bioscience developments.

Hospital and family doctors came top of of those most trusted to take regulatory decisions on the public's behalf ( 57 per cent). Retailers topped the list of those least trusted to take such decisions.

E.M.

\section{South Africa reveals plans to make AIDS a notifiable disease}

[CAPE TOWN] South Africa's minister of health, Nkosazana Zuma, has proposed that AIDS be made a notifiable disease in South Africa, in an attempt to reduce the spread of the infection which now affects one in ten South Africans.

The proposals would require doctors to inform local health authorities (anonymously) of persons diagnosed as having AIDS, as well as immediate family members and healthcare workers involved in the treatment of the patient. AIDS, rather than just 'natural causes', must be recorded as the cause of death on death certificates.

But the proposals have raised concern that, if the government were to go one step further and deny entry to South Africa to people who either have AIDS or are HIVpositive, this would pose a serious problem for delegates to the World AIDS Congress, scheduled to take place next year in Durban.

Announcing the proposals at a joint meeting last month with the health ministers from Namibia and Zimbabwe, Zuma said: "We can't afford to be dictated to

by human rights or AIDS activists. We want to know who is dying of AIDS, and relatives and partners must be notified. It is time we treated AIDS as a public health issue like TB. We don't go about treating that with secrecy."

No changes have been proposed for those who are HIV-positive, which does not need to be reported. The government has invited comments on the proposals before it promulgates the regulations.

Meanwhile, Ian Roberts, a special adviser on health affairs to Zuma, has issued a

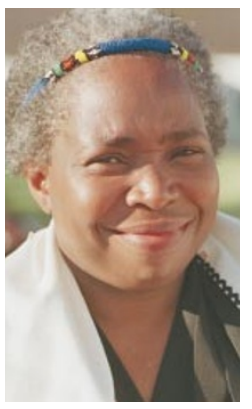

Zuma: ending the secrecy over AIDS. statement denying press reports that Zuma changed her mind about using the antiAIDS drug AZT for the prevention of motherto-child transmission (see Nature 396, 504; 1998). The reports appeared after the provincial government of Gauteng allowed the Chris Hani
Baragwanath Hospital in Johannesburg to accept a donation from UNAIDS to cover the cost of using the drug in research trials.

Mark Wainberg, chairman of the International AIDS Society, says he remains strongly opposed to any moves to boycott next year's conference in protest at the minister's stance. "There is consensus among its scientific community, including some of Zuma's most severe critics, that holding the meeting in South Africa will do far more good than harm," he says. "We should press ahead - unless something as horrible as a restrictive border-crossing policy were to be imposed."

In another development, Zuma has informed the US pharmaceutical company Bristol-Myers Squibb that the government could not endorse a proposal to invest $\$ 100$ million over the next five years on AIDSrelated research in South Africa, including clinical trials on their products (see Nature $399,96 ; 1999)$. The initiative was announced earlier this month without the prior consent of the government.

Michael Cherry 